NBER WORKING PAPER SERIES

\title{
STRATEGIC TRADING IN A TWO-SIDED FOREIGN EXCHANGE AUCTION
}

\author{
Linda Goldberg \\ Rafael Tenorio
}

Working Paper No. 5187

\author{
NATIONAL BUREAU OF ECONOMIC RESEARCH \\ 1050 Massachusetts Avenue \\ Cambridge, MA 02138 \\ July 1995
}

Linda S. Goldberg is grateful for the research support provided by the C.V. Starr Center for Applied Economics, the National Science Foundation, and the Social Science Research Council. Jeffrey Bergstrand, Richard Lyons, Paula Tkac, and seminar participants at the 1995 Econometric Society winter meetings, the Spring 1995 Midwest International Economics meetings, New York University, and Purdue Krannert School of Management provided useful comments. Mr. Youngduk Kim of New York University provided valuable research assistance. This paper is part of NBER's research program in International Finance and Macroeconomics. Any opinions expressed are those of the authors and not those of the National Bureau of Economic Research.

(C) 1995 by Linda Goldberg and Rafael Tenorio. All rights reserved. Short sections of text, not to exceed two paragraphs, may be quoted without explicit permission provided that full credit, including $(\odot$ notice, is given to the source. 


\title{
STRATEGIC TRADING IN A TWO-SIDED \\ FOREIGN EXCHANGE AUCTION
}

\begin{abstract}
The market microstructure chosen for foreign exchange markets can influence trading volumes and equilibrium exchange rates. With emerging markets and developing countries increasingly utilizing two-sided auctions, we show that the choice of the discrete "tâtonnement" auction creates incentives for strategic behavior among market participants. We provide theoretical predictions on strategic under-revelation of demand or supply positions that are supported empirically using detailed data from a rare example of a tâtonnement market, the Moscow Interbank Currency Exchange. Our results also are consistent with findings from experimental work on auctions: new entrants altered strategic behavior mainly on the market's demand side, without comparable implications for the supply side. We also show that bids and offers were influenced by fundamentals and specific policy measures.

Linda Goldberg

Department of Economics

New York University

269 Mercer Street

New York, NY 10003

and NBER

Rafael Tenorio

College of Business Administration

University of Notre Dame

Notre Dame, IN 46556
\end{abstract}




\section{Strategic Trading in a Two-Sided Foreign Exchange Auction}

\section{Introduction}

The microstructure of a foreign exchange market can influence trading volumes and equilibrium exchange rates. In recent years, a variety of auction-like mechanisms have been used for foreign exchange trade, especially in developing and transition economies. Two basic classes of auctions have been used. In a one-sided auction, the monetary authority collects foreign exchange proceeds from exporters and after some official retention sells the balance to private foreign exchange users. In a two-sided auction, foreign exchange recipients and users meet in a central marketplace in discrete trading sessions. ${ }^{2}$

A noteworthy type of two-sided market is the "tâtonnement" auction, named after the analogous market-clearing mechanism proposed by Walras more than a century ago. In this auction, buyers and sellers submit foreign exchange orders at a price announced by the auctioneer or market maker. The price is then adjusted in steps in the same direction as the aggregate excess demand. The market clears at the price where the aggregate excess demand vanishes. Since orders are executed only in equilibrium, the tâtonnement is a "competitive" price mechanism. ${ }^{3}$ This mechanism is in contrast to alternative two-sided mechanisms like double auctions, where different traders may transact at different prices. ${ }^{4}$

Very little is known about the empirical properties of tâtonnement markets. Besides Jarecki's (1976) account of the London gold market, and some experimental work (Joyce 1984, Bronfman et. al. 1994), we are not aware of any other documented cases of markets working in a similar fashion. This near absence of tâtonnement experiences is underscored in the survey by

\footnotetext{
${ }^{2}$ Feldman and Mehra (1993) provide a recent typology of auction micro-structures.

${ }^{3}$ A similar pricing system is observed in "call" or two-sided "batch" auctions used in securities trading.

${ }^{4}$ Walker (1972) and Morishima (1977, Chapter 2) provide conceptual and historical accounts of the Walrasian tatonnement.
} 
Friedman (1993). As a result of this dearth of experiences, we may lack a good understanding of the implications of choosing this auction structure.

This paper is oriented toward generating some useful theoretical and empirical insights about trader behavior and outcomes in tâtonnement foreign exchange markets. First, we provide theoretical results on strategic behavior given the rules of this type of auction, and demonstrate the results using a simple example. Second, we present evidence from our examination of detailed data from a rare example of a tâtonnement market at work, the Moscow Interbank Currency Exchange (MICEX). Third, we relate our findings to relevant lessons generated from work in experimental economics.

Our analysis highlights strategic trading that occurs independently of informational asymmetries or imperfections. The emphasis we place on the importance of market power rather than informational asymmetries complements an existing and emerging body of research on alternative foreign exchange market microstructures. ${ }^{5}$ We show that, even under perfect information, the tâtonnement market mechanism may encourage strategic "under-revelation" of demands or supplies by participants who perceive that, because of their relative size, they have the ability to influence equilibrium prices and shift the surplus in their favor.

The intuition behind the strategic behavior is straight-forward: if a participant in the market can understate his excess demand and can thereby lower the price on all units (of foreign exchange) that he purchases, the market surplus will shift in his favor. Likewise, if the market power is concentrated in the supply side of the market, supply will be understated and, through making supply scarcer, the participant will attempt to secure a higher price for his units supplied

${ }^{5}$ Lyons (1993) pursues the link between alternative models of foreign exchange trading activity and market volumes under informational asymmetries. Unlike Lyons' work wherein the models and data pertain to continuous trading mechanisms, our work concentrates mainly on the periodic auction which is more pertinent for much less mature foreign exchange markets. 
to the market. In Section II we show this result formally based on a typical trader's problem and a specific illustrative example. Our theoretical results further demonstrate that when new players enter a market, alterations in the degree of under-revelation can be detected by analysis of slopes and intercepts of bid and order functions for foreign exchange.

In the empirical section of our paper (Section III) we examine detailed bid and offer activity at the Moscow Interbank Currency Exchange (MICEX) established in Russia in $1991 .^{6}$ Our analysis of this foreign exchange market provides empirical support to the strategic underrevelation hypothesis for tâtonnement auctions. We conclude that early efforts of broadening access to the MICEX market had mixed effects on the price-setting behavior of traders. New entrants may have eroded the monopsony power of purchasers of foreign exchange, but did not significantly weaken the power of existing players on the supply side of the market. Our empirical findings are consistent with prior conclusions generated in experimental economics. Finally, we also study the implications for MICEX market outcomes of macroeconomic fundamentals and a set of "events". This analysis confirms that Russian foreign exchange markets are indeed responsive to fundamentals and these should be included in any time series analysis of market microstructure themes. Section IV concludes and suggests directions for further research.

\section{Analytical Issues: Market Structure, Trader Behavior, and Outcomes}

Consider a market external to the United States in which foreign exchange, which we refer to as dollars, is traded for domestic currency. The real exchange rate relevant for decision-making by traders is denoted by $e$, i.e. the value of domestic currency relative to units of foreign exchange. Let $e_{0}$ be the exchange rate which the market in the previous period. At

\footnotetext{
${ }^{6}$ According to Kovanen (1994), Romania has recently experimented with tatonnement foreign exchange auctions.
} 
the opening of the current trading session, market participants submit preliminary applications indicating the quantities demanded $\left(x^{d}\right)$ or supplied $\left(x^{s}\right)$ at the initial rate $e_{0} \cdot{ }^{7}$ Since any agent $i(i=1, \ldots, n)$ may potentially be a buyer or a seller, we lose no generality by concentrating on each agent's excess demand $x_{i}=x_{i}^{d}-x_{i}^{s}$. Trader i's excess demand function is defined as $x_{i}(e)$, where $\partial x_{i} / \partial e<0$. This excess demand function will also depend on other exogenous fundamental forces in the economy which we will discuss further in Section III. If we define the initial aggregate excess demand as $X\left(e_{0}\right)=\sum_{i=1}^{n} x\left(e_{0}\right)$, the tâtonnement process dictates that a market-maker or "auctioneer" use a rule $f(X(e))$, where $f>0$ and $f(0)=0,8$ to modify the prevailing exchange rate until the excess demand vanishes and the market reaches its equilibrium, i.e., when $x\left(e^{*}\right)=0$ at the rate $e=e^{*}$.

If agent $i$ is small enough with respect to the aggregate, and also believes that everybody else is, the noncooperative equilibrium of a tâtonnement market approaches the Walrasian perfectly-competitive outcome (Schmeidler 1980). In this case, each agent cannot do any better than reveal her true excess demand at each price quoted by the auctioneer. Samuelson (1954) also showed that, when agents are very small with respect to the aggregate, the competitive process makes it unprofitable to depart from the rules of perfectly competitive behavior when everyone else continues to abide by these rules.

Unlike the purely competitive case, there is room for strategic behavior in tâtonnement markets with a small number of traders or where some large traders have market power. Vickrey (1961) points out that when agents perceive that their stated excess demands affect the direction and magnitude of price changes, they will have the incentive to understate these

\footnotetext{
${ }^{7}$ Time subscripts are omitted. These subscripts are introduced in Appendix A for the dynamic trading problem and in the empirical work of Section III.

${ }^{8}$ See Morishima (1977) and Joyce (1984) for the technical aspects related to this function.
} 
excess demands. Hurwicz (1972) also observes that when an agent has positive measure it would pay for him to "falsify" his true preferences when everyone else follows the rules of perfect competition. The extent of under-revelation diminishes as a market becomes more competitive and approaches the Walrasian case.

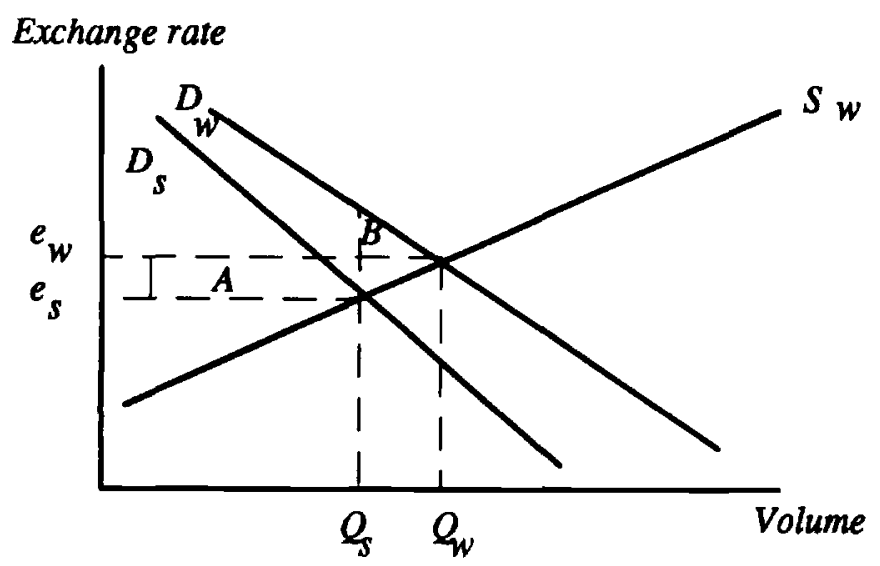

Strategic Demand

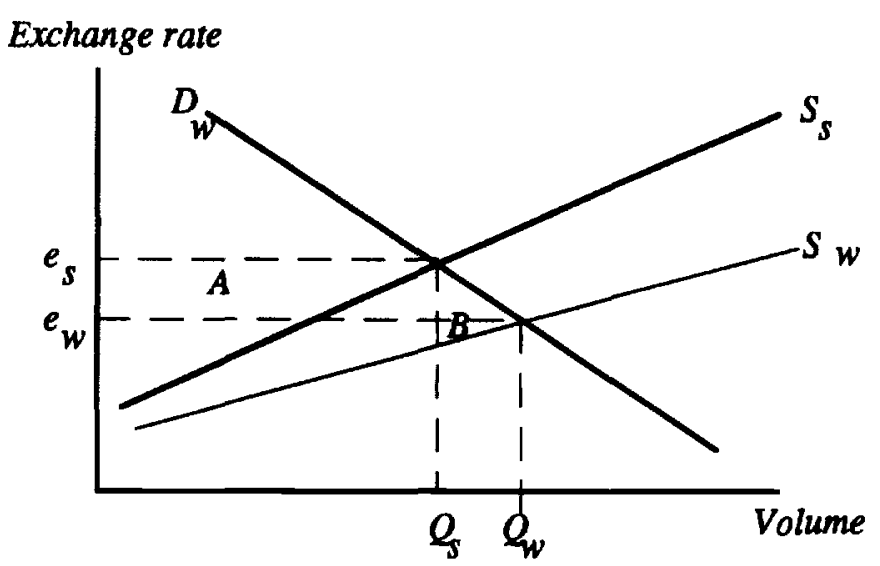

Strategic Supply

Figure la and $1 \mathrm{~b}$

The basic implications of strategic under-revelation are illustrated graphically in Figures la and lb. The figures show basic FOREX currency supply and demand curves, illustrating both the Walrasian curves (subscript $w$ ) and the curves which include under-revelation when the respective sides of the market have concentrated power (subscript $s$ for strategic). Net gains from the strategic play are shown by the area A-B. If buyers (sellers) understate their true quantities demanded (supplied), the theory predicts that (i) the equilibrium price will be lower (higher) than the Walrasian price, and (ii) the quantity transacted will be lower, regardless of which group behaves strategically. Hence, in the FOREX market concentration among buyers of foreign exchange will promote real exchange rate appreciation, while concentration among the sellers of foreign exchange will contribute to real exchange rate 
depreciation. Concentration on either side of the market unambiguously contributes to overall market thinness.

\section{IIA: A Typical Trader's Problem}

In this section we present a typical trader's decision making problem when he submits his excess demand message in a tâtonnement market. Trader $i$ 's objective is to maximize the net value of his foreign exchange trade, ${ }^{9}$

$\operatorname{Max}_{X_{i}} V_{i}\left(x_{i}\right)-e\left(x_{i}+\sum_{j=1, \neq i}^{n} x_{j}\right) x_{i}$

where $x_{i}$ is $i$ 's quantity of foreign exchange, $V_{i}\left(x_{i}\right)$ is the value that trader $i$ places on $x_{i}$, $e(\cdot)>0$ is the exchange rate, and $j$ indexes all traders other than $i$. $x_{i}$ is positive for purchasers and negative for sellers. The value function is associated with (i) purchasing foreign exchange for imports; or (ii) selling foreign exchange from export proceeds.

Because of the competitive pricing structure of this market, the excess demand message of a single trader is binding only in equilibrium, i.e. when all of the traders' messages are consistent and the market clears. For this reason, the equilibrium exchange rate $e(\cdot)$ is a function of the stated excess demands of all market participants. The necessary condition for a Nash equilibrium at $\left(x_{i}^{*}, x_{j}^{*}\right)$ is

$V_{i}^{\prime}\left(x_{i}^{*}\right)-e\left(x_{i}^{*}+\sum_{j=1, \neq i}^{n} x_{j}^{*}\right)-x_{i}^{*}\left[\partial e(\cdot) / \partial x_{i}^{*}+\sum_{j=1, \neq i}^{n}\left(\partial e(\cdot) / \partial x_{j}^{*}\right)\left(\partial x_{j}^{*} / \partial x_{i}^{*}\right)\right]=0$

\footnotetext{
${ }^{9}$ In Appendix A we extend the objective and valuation functions to include intertemporal considerations. As shown in the present section, the specified problem is most directly relevant when trading is dominated by transactions needs, i.e. for import- and export-based activities.
} 
An important feature of this market is that no real time information is released when the bids and offers are submitted, which means that traders cannot sequentially react to the actions of their opponents within a single round. Thus, as in a Cournot model, the conjectural variation $\partial x_{j}^{*} / \partial x_{i}^{*}$ is equal to zero for all $j$. Accordingly, the necessary condition (2) is rewritten as:

$$
V_{i}^{\prime}\left(x_{i}^{*}\right)-e\left(x_{i}^{*}+\sum_{j=1, \neq i}^{n} x_{j}^{*}\right)-x_{i}^{*}\left[\partial e(\cdot) / \partial x_{i}^{*}\right]=0
$$

If agent $i$ is a buyer of foreign exchange the third term in $\left(2^{\prime}\right)$ is positive and $V_{i}^{\prime}\left(x_{i}^{*}\right)>e(\cdot)$, which means that $i$ under-reveals the true marginal value of his bid quantity and bids for fewer units than prescribed by his Walrasian demand. Analogously, if $i$ is a seller of foreign exchange, $v_{i}^{\prime}\left(x_{i}^{*}\right)<e(\cdot)$, so that sellers require a price higher than their marginal valuation of the units sold. In comparison with Walrasian behavior, at every exchange rate sellers offer fewer units of foreign exchange for sale at the auction.

The linkage between under-revelation and the structure of the market is straight-forward to illustrate. Manipulation of equation (2) yields:

$$
V_{i}^{\prime}\left(x_{i}^{*}\right)=e(\cdot)\left[1+\frac{\partial e}{\partial X} \frac{X}{e} s_{i}\right]=e(\cdot)\left[1+\frac{s_{i}}{\varepsilon}\right]
$$

where $\varepsilon$ is the price elasticity of the market's excess demand function and $s_{i}=x_{i} /\left(x_{i}+\sum_{j=1, \neq i}^{n} x_{j}\right)=x_{i} / X$ denote $i$ 's market share. Clearly, as $s_{i} \rightarrow 0$, representing the competitive case, then $V_{i}^{\prime} \rightarrow e(\cdot)$ and under-revelation disappears. Conversely, as the market share of a player increases, then under-revelation increases. The limiting case of $s_{i}=1$ depicts the behavior of a monopolist or monopsonist. ${ }^{10}$

\footnotetext{
${ }^{10}$ Appendix A shows that under-revelation also arises if a speculative motive is present. Agents with market power recognize that their speculative actions alter the price of foreign exchange in a direction which reducing to some degree the profitability of this speculation and raising the cost of all units of foreign exchange
} 
An Example: For simplicity, consider a two-sided market where the supply side consists of a fringe of competitive agents and the demand side is composed of potentially strategic agents. This setup permits us to develop further insights into the behavior of market participants while avoiding issues of indeterminacies of equilibria that are associated with bilateral monopolies or oligopolies. In particular, we use the example to demonstrate the implications of underrevelation for the slopes and intercepts of demand and supply functions for foreign exchange.

Suppose that the competitive supply is represented by a linear function

$e=c X, \quad c>0$

Trader $i$ is a net purchaser of foreign exchange, with a valuation function:

$$
V_{i}\left(x_{i}\right)=a x_{i}-b x_{i}^{2}, \quad x_{i} \leq a / 2 b \quad a, b>0
$$

If $i$ is the sole trader on the demand side, the Nash equilibrium demand function is

$$
x_{i}=\frac{a}{2 b}-\frac{e}{b}
$$

If a second identical trader $j$ joins the demand side, Nash equilibrium market demand is:

$$
X=x_{i}+x_{i}=\frac{a}{b}-\frac{3 e}{2 b}
$$

By contrast, if both players were Walrasian (competitive) agents, the demands in the one and two-agent cases would be:

$$
x_{i}=\frac{a}{2 b}-\frac{e}{2 b}, \text { and }
$$

purchased today. This recognition of market power leads the agent to purchase less foreign exchange today than would be the case in the absence of market power. Our results that strategic under-revelation also arises in a dynamic setting accord with the general discussion by Madhavan (1992). 


$$
X=x_{i}+x_{j}=\frac{a}{b}-\frac{e}{b}
$$

Setting demand equal to supply, the equilibrium quantities and exchange rates in each case are:

\begin{tabular}{|l|l|l|l|l|}
\hline & monopsony & duopsony & $\begin{array}{l}\text { one competitive } \\
\text { player }\end{array}$ & $\begin{array}{l}\text { two competitive } \\
\text { players }\end{array}$ \\
\hline quantity & $a / 2(b+c)$ & $2 a /(2 b+3 c)$ & $a /(2 b+c)$ & $a /(b+c)$ \\
\hline exchange rate & $c a / 2(b+c)$ & $2 c a /(2 b+3 c)$ & $c a /(2 b+c)$ & $c a /(b+c)$ \\
\hline
\end{tabular}

The strategic under-revelations $S U$ with one and two strategic players on the demand side are:

$$
\begin{aligned}
& S U(\text { monopsony })=\frac{a c}{(2 b+c)(2 b+2 c)} \\
& S U(\text { duopsony })=\frac{a c}{(b+c)(2 b+3 c)}
\end{aligned}
$$

Subtracting (10b) from (10a),

$S U($ monopsony $)-S U($ duopsony $)=\frac{a c^{2}}{2(b+c)(2 b+c)(2 b+3 c)}>0$

which implies that increased participation on the demand side unambiguously leads to reduced under-revelation. Plotting the market demand functions for these cases provides additional insights on the impact of under-revelation on the slopes and intercepts of these functions.

Observe from Figure 2 that, as conjectured, strategic demands ( $M$ and $D$ ) display underrevelation of quantities when compared with Walrasian demands ( $w 1$ and $w 2$ ). This underrevelation is stronger in the one agent case, where the stated demands are steeper. Our example also shows that the demand quantity intercepts are equal in the strategic and Walrasian cases, both in the context of one and two buying agents. This result is because the gains from under-revelation disappear as the price approaches zero. Thus, in this setup, the 
difference in the quantity intercepts between monopsony and duopsony are purely due to aggregation, i.e. they reflect a pure volume effect. Decreased under-revelation that results from increased participation must necessarily appear as a reduction of the absolute value of the slope of the market demand function. ${ }^{11}$

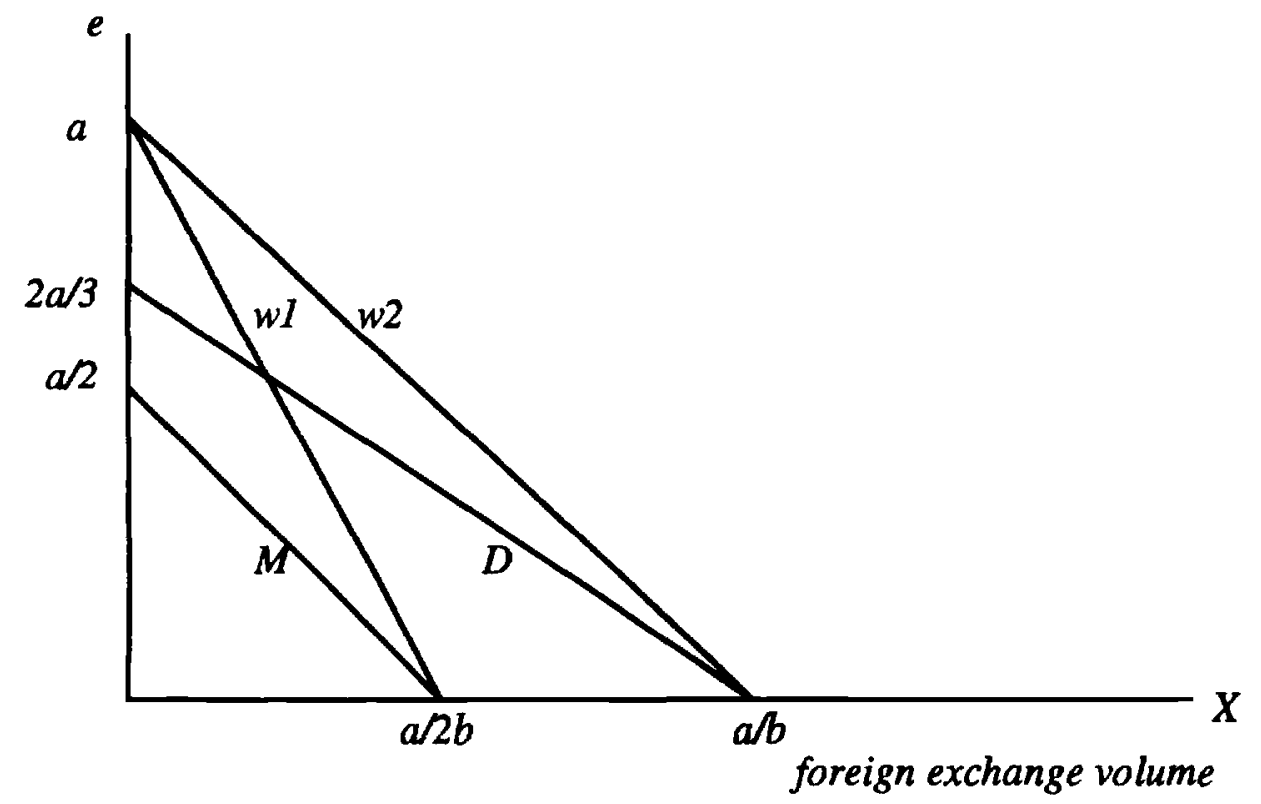

M: Monopsony; $D$ : Duopsony; $w 1$ : one Walrasian buyer; $w 2:$ two Walrasian buyers.

Figure 2

How are the volume and under-revelation effects reflected in the slope of the market demand functions? Consider the following case: a non-strategic (Walrasian) agent indexed by " $-i$ " is added to the demand side which already contained a single strategic player. Then equilibrium demands satisfy

\footnotetext{
${ }^{11}$ Inclusion of a second trader with a smaller intercept or slope does not alter the results significantly. The only difference between this case and the example provided in the text is that the Walrasian single agent will buy more at high prices than the two competitive agents. Since Walrasian demands only provide a benchmark and are unobservable in practice, testable hypotheses are unaltered.
} 
$2 a-2 b\left(x_{i}+x_{-i}\right)-2 c\left(x_{i}+x_{-i}\right)-c x_{i}=0$

Without loss of generality, we can assume that $x_{i}=k\left(x_{i}+x_{-i}\right)$, where $k$ is agent $i$ 's share of the market quantity. Since $i$ and $-i$ are identical in every respect, except for $i$ 's under-revealing behavior, $k \in(0,1 / 2)$, and equilibrium market demand is given by:

$x_{i}+x_{-i}=\frac{a}{b}-\frac{(2+k)}{2 b} e, \quad k \in(0,1 / 2)$

The slope and intercept of this new market demand curve can now be compared with those of the previously discussed cases of monopsonist, duopsonist, and Walrasian agents. The exchange rate intercept for this case is $\hat{e} \in(4 a / 5, a)$.

As shown in Figure 3, an additional participant has two potential effects. First, if the extra player is strategic, the resulting equilibrium reflects a relative reduction in underrevelation and appears as the duopsonist case, $D$. However, if the player is non-strategic, the resulting equilibrium reflects demands that appear as the $M+w I$ case. In this latter scenario, the rotation of demand reflects volume effects on the market, not changes in under-revelation or strategic behavior. In Figure 3 the $M+w 1$ equilibrium market demand is drawn for the mean value of $k=1 / 4$, which results in $\hat{e}=9 a / 10$. Observe that, on average, the slope of $M+w l$ is substantially closer to the purely competitive case $w 2$ than it is to the duopsony case. This shows that as new players enter the market changes in the slope of the market demand function are mainly due to under-revelation. 


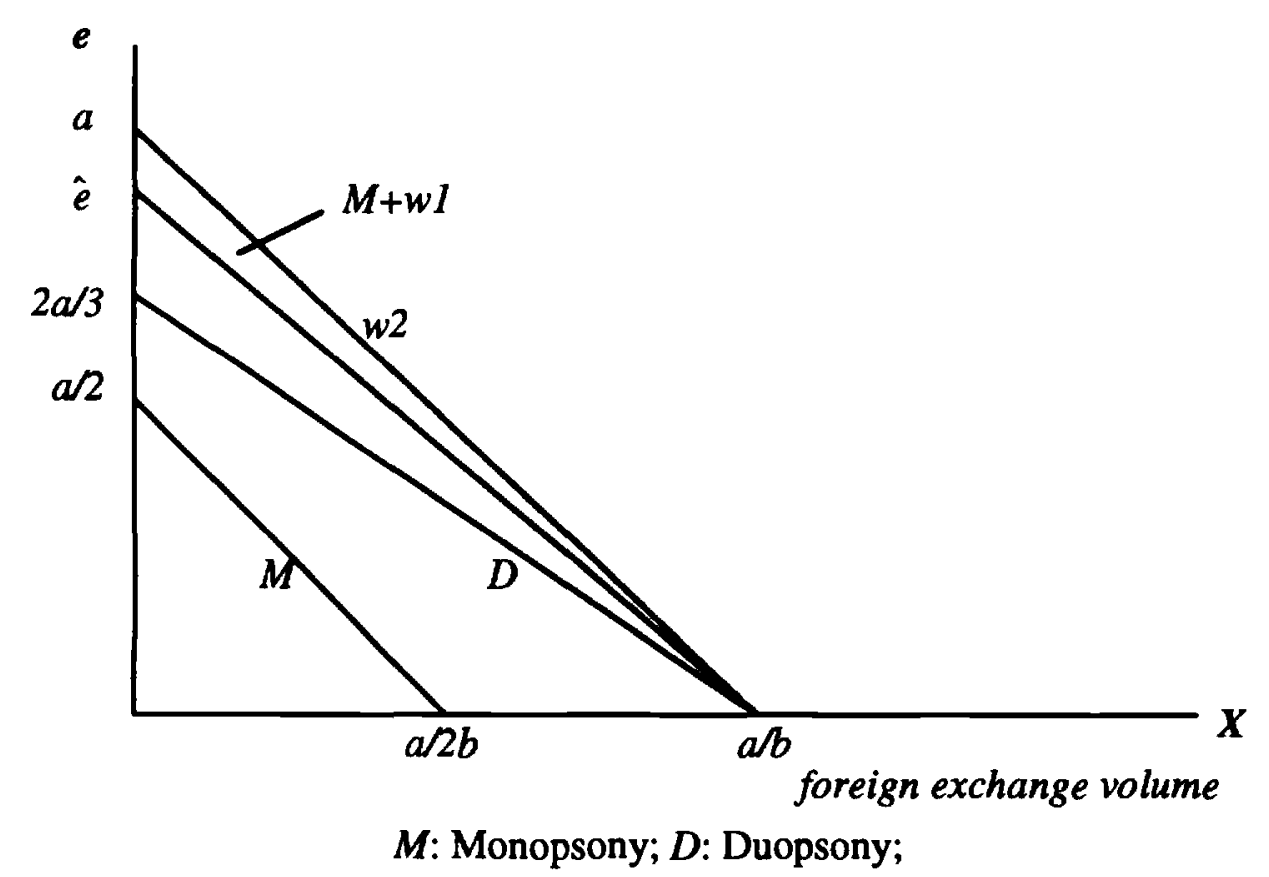

$M+w 1$ : one Walrasian buyer plus one strategic buyer; $w 2$ : two Walrasian buyers.

Figure 3

From our numerical example the change in (inverse) demand slope from $M$ to $D$ can be decomposed as follows:

Total Slope Change (from $M$ to $D$ )

Slope Change from $M$ to $M+w I$ (volume)

Slope Change from $M+w I$ to $D$ (under-revelation)
$9 b / 18$

$2 b / 18$

$7 b / 18$

Approximately 80 percent of the slope change is due to under-revelation or strategic effects, while only 20 percent of the slope change is due to addition of a perfectly-competitive player to the market. Comparable examples based on changing some of the initial assumptions yield qualitatively similar results. If the supply side of the market for foreign exchange were instead modeled as containing a mix of strategic and competitive players, analogous results about the intercepts and slopes of the market supply function would arise. 


\section{Analysis of the Russian tâtonnement foreign exchange market}

A. Description of Russia's foreign exchange auction: The main trading place is the Moscow Interbank Currency Exchange (MICEX), wherein both buyers and sellers of foreign exchange (FOREX) interact and the market discretely clears at each session using tâtonnement rules. The number of banks participating in the MICEX auctions, as well as the volumes of foreign exchange transactions, have risen dramatically since the inception of the current auction format in January 1992. ${ }^{12}$ From the arguments presented in Section II, we expect that the number of auction participants could have a significant effect on the slopes and intercepts of market demand and supply.

The auction clearing procedure is as follows: the exchange rate quoted at the previous trading session is taken as the opening exchange rate for the day. Prior to each trading session currency dealers submit preliminary applications for selling and/or buying foreign currency. In these applications, foreign exchange cannot be purchased as a price lower than the opening rate or sold at a price higher than the opening rate. If there exists an imbalance between initial currency bids and offers, the exchange rate is adjusted in fixed increments by the auctioneer. Dealers then have the opportunity to revise their bids and offers. This process continues until desired volumes from both sides of the market are balanced.

B. The Valuation of Foreign Exchange Bids and Offers: Bids and offers for foreign exchange at the auctions depend on the economic fundamentals which influence agent valuation functions. These fundamental determinants include: (a) the expected opportunity cost of

\footnotetext{
12For a more detailed discussion of this market, see Goldberg (1993) and Goldberg and Tenorio (1995). Foreign exchange auctions began in November 1989 in Russia (the USSR at that time) and were held weekly throughout most of 1991. While the MICEX was not the formal trading institution until January 1992, the largest players in this currency market participated in the earlier auctions. The interbank market met weekly from April 1991 through March 1992. The market then met bi-weekly until early June 1993 when trading expanded to four sessions per week, and further expanded to five sessions per week later in June 1993.
} 
holding rubles, represented by the domestic nominal interest rate net of the domestic rate of inflation, $i_{t}-\pi_{t} ; 13$ (b) the profitability of leakages into black markets, represented by the black market premium, $\delta_{t-1} ; 14$ and (c) a vector of zero-one dummy variables $Z_{t}$ reflecting the policy changes -- both actual and anticipated. These events dummies are summarized in Appendix Tables 1 and 2.15 Policy measures which could have influenced demand or supply for foreign exchange include changes in bank licensing, regulation of foreign currency transactions, regulation of external trade activity, the foreign exchange surrender regime, and incentives transmitted through inter-related markets.

Intertemporal Considerations: In addition to the aforementioned fundamentals which introduce dynamic considerations into agent decisions, three other intertemporal considerations associated with learning and institutional delays arise from micro-market perspectives. First, traders can learn about their valuations of foreign exchange relative to market valuations. The value of the dollar is neither exogenously given to each trader (the "private values" paradigm), nor is it common to all traders (the "common values" paradigm). Rather, a trader's value may be linked to both his (private) ability to use or "transform" dollars, as well as to economy-wide

\footnotetext{
${ }^{13}$ We assume that the contemporaneous and expected inflation rates are equal. In calculating the annual inflation rates, January 1992 and the week of January 5, 1993 yield very high numbers since price reforms occurred at these dates. A dummy variable is added to the regressions to capture these high inflation/ price reform periods. The real interest rate is constructed using the interbank market interest rate. Since the real interest rate in Russia is negative throughout our sample period we use the negative of the real interest rate in regressions, i.e. inflation less the nominal interest rate, in order to take logarithms of this variable. Two key interest rate series operated in Russia during the period of our analysis. A government controlled fixed interest rate, the Central Bank refinance rate, is used for commercial bank borrowing from the Central Bank. Since new commercial banks rarely rely on CBR credits for their funds and instead rely more on interbank loans, the rate that we use in our analysis is the flexible interbank market interest rate.

${ }^{14}$ Since auction and black market exchange rates are simultaneously determined, we proxy the profitability of leakages by the lagged black market premium. This premium is constructed using cash exchange rates and "effective" MICEX exchange rates. The data appendix provides further details. Goldberg and Karimov (1995a, 1995b) provide a more thorough examination of the economic importance of black markets for foreign exchange.

${ }^{15}$ Institutional details and further discussion of policy changes are provided in Goldberg and Tenorio (1995).
} 
(common) considerations. Thus, in a FOREX auction, the currency traded falls within the category of "correlated values," which implies that a trader may learn about his value by observing signals within as well as outside of the market.

Second, traders may become more experienced at playing the game and at disentangling opponents' strategies after repeated sessions. Repetitions also may make strategic agents more aware of their price-setting power and become more skilled at captaring potential surpluses over time. Dynamic behavior by such agents was confirmed in the results of Joyce's (1984) experiment using tâtonnement auctions: when players on the supply side of the market were segregated from players on the demand side so that more information accrued about each side's depth, the relative surplus of the more skilled group (the buyers) increased in successive repetitions.

Third, trading may simply be linked across periods because of institutional delays which slow the implementation of desired behaviors by market participants. In each period there may be dampened effects of shocks from previous periods. We will deal with these issues in our econometric work by adjusting for heteroskedasticity and serial correlation of residuals. These problems may arise because the trader's accuracy of play may change over time and be systematically related to the error term. We also account for dynamic activity by examining whether inclusion of lagged dependent variables influence current values of the dependent variables.

C. Estimating Equations and Data: The estimation period is January 1, 1992 through August 31,1993 . Our testing equations for supply and demand at the auction take the form:

$$
\begin{aligned}
X_{t}^{\text {initial }}= & \alpha_{0}+\alpha_{0, j} B d u m_{t}^{j}+\left(\alpha_{1}+\alpha_{2, j} \text { Bdum }_{t}^{j}\right) \cdot R E R_{t-1}+\alpha_{3} \cdot\left(-i_{t-1}+\pi_{t-1}\right) \\
& +\alpha_{4} \cdot z_{t}+\alpha_{5} \cdot \delta_{t-1}+\alpha_{6} \cdot X_{t-1}^{i n i t i a l}+\mu_{t}
\end{aligned}
$$


where $X_{t}^{\text {initial }}$ is either the logarithm of initial bids for foreign exchange $\left(X_{t}^{d \text {,initial }}\right)$ or the logarithm of initial offers of foreign exchange $\left(X_{t}^{s, \text { initial }}\right) .{ }^{16} Z$ represents a vector of events dummies. ${ }^{17}$ The logarithm of the real exchange rate $R E R$ enters with both a constant coefficient and with an interactive dummy coefficient. The dummy variable vector $B d u m_{l}^{j_{18}}$ delineates discrete groupings of numbers of auction participants and changes in the regulation of auction participation: $j=1$ refers to bank participation rates of more than 41 banks; $j=2$ refers to participation by 52 or more banks; $j=3$ corresponds to June 30, 1993 onwards and delineates the tightening of regulation on bank capitalization in relation to foreign exchange holdings. The dates for which these dummy variables are zero and one are summarized in Table 1.

\footnotetext{
${ }^{16}$ We do not use equilibrium trade volumes as the dependent variables because these quantities are likely to be significantly distorted by CBR foreign exchange intervention. In principle, intervention occurs only after the initial bids and offers are reported, however, in practice there is little concrete information about the procedures for intervention.

${ }^{17}$ Within this vector, dummy names refer to the specific events. The prefix "tx" refers to changes in export policy, "tm" to import policy, and "ar" to announcements of pending reforms. Particular reforms are indicated by a date suffix. Announcement dummies are equal to zero for three weeks following and inclusive of an announced policy initiative. The exception is the February 5, 1993 dummy, since this announced initiative was quickly retracted. Rdum and Parliam dummy variables are used in all regressions. Rdum is one during price reform periods of January 1992 and the first week of January 1993. This term is introduced into the regression equations to offset extreme values of annualized inflation that enter through the real interest rate term. Parliam is one during the parliamentary coup and zero otherwise.

${ }^{18}$ The perceived market structure is assumed to be identical to the actual market structure in any auction since more detailed information about perceptions is unavailable. In practice, once trading begins in a market, strategic interactions and deviations from Walrasian supply can occur in a variety of ways.
} 
Table 1 Dates of Dummies for Numbers of Banks Participating in Auctions

\begin{tabular}{|l|l|l|l|}
\hline $\begin{array}{l}\text { bdum } 1=\text { bdum } 2= \\
\text { bdum } 3=0\end{array}$ & $\begin{array}{l}\text { bdum } 1=1 ; \\
\text { bdum } 2=b d u m 3=0\end{array}$ & $\begin{array}{l}\text { bdum } 1=b d u m 2=1 ; \\
\text { bdum } 3=0\end{array}$ & $\begin{array}{l}\text { bdum } 1=\text { ddum } 2= \\
\text { bdum } 3=1\end{array}$ \\
\hline $1 / 3 / 92-7 / 24 / 92$ & $7 / 28 / 92-10 / 2 / 92 ;$ & $10 / 6 / 92-10 / 27 / 92 ;$ & $7 / 6 / 93-11 / 16 / 93$ \\
& $10 / 13 / 92-10 / 23 / 92 ;$ & $12 / 8 / 92-3 / 5 / 93 ;$ \\
& $11 / 3 / 92-12 / 4 / 92$ & $3 / 16 / 93-7 / 2 / 93$ & \\
\hline
\end{tabular}

The use of the Bdum vector in the estimating equation is intended to address the impact of potentially altering the competitive structure of the market by introducing new players or eliminating small undercapitalized players. This could have an effect on the slopes and intercepts of the estimated bid and offer functions for foreign exchange. When players are added to the market, which occurs incrementally with $b d u m I=1$ and then with $b d u m 2=1$, the expected effects on the regression intercept and slope are as summarized in Table 2. By contrast, the third dummy variable reflects the potential elimination of (undercapitalized) players from the auction, so we might observe the opposite sign pattern of coefficients associated with $b d u m 3=1$.

Table 2 Strategic Under-revelation and Regression Coefficients

\begin{tabular}{|l|l|l|l|l|}
\hline $\begin{array}{l}\text { Implications of new entrants into the } \\
\text { tâtonnement auction market }\end{array}$ & \multicolumn{2}{|c|}{$\begin{array}{l}\text { Demand for Dollars } \\
\text { Effects on Estimated: }\end{array}$} & \multicolumn{2}{c|}{$\begin{array}{l}\text { Supply of Dollars } \\
\text { Effects on Estimated: }\end{array}$} \\
\cline { 2 - 5 } & intercept & slope & intercept & slope \\
\hline $\begin{array}{l}\text { diffusion of existing volumes: a change in } \\
\text { competitive structure of the market only }\end{array}$ & $\alpha_{0, j}=0$ & $\alpha_{2, j}>0$ & $\alpha_{0, j}=0$ & $\alpha_{2, j}<0$ \\
\hline no change in under-revelation & $\alpha_{0, j}>0$ & $\begin{array}{l}\alpha_{2, j}<0 \\
\text { (weak) }\end{array}$ & $\alpha_{0, j}>0$ & $\begin{array}{l}\alpha_{2, j}>0 \\
\text { (weak) }\end{array}$ \\
\hline $\begin{array}{l}\text { reduced under-revelation by strategic } \\
\text { players }\end{array}$ & $\alpha_{0, j}>0$ & $\begin{array}{l}\alpha_{2, j}<0 \\
\text { (strong) }\end{array}$ & $\alpha_{0, j}>0$ & $\begin{array}{l}\alpha_{2, j}>0 \\
\text { (strong) }\end{array}$ \\
\hline
\end{tabular}


The data on initial foreign exchange bids, initial foreign exchange offers, and other series used in the regressions are described in Table 3. The means, standard deviations, minimum values, maximum values, and unit root features are summarized. In the early part of our sample period, January through March 1992, average weekly transaction volumes were US\$11.30 million. By the summer of 1993, average weekly transaction volumes had elevated to US\$266.34 million. Excess initial demand relative to market volumes was considerably higher in absolute terms in the early part of the sample but varied considerably over time. Both bid and offer data exhibited positive trends. None of the volume data or the real exchange rate series have unit roots. ${ }^{19}$

The initial bid and offer data represent the activities of the private agents participating in both sides of the MICEX market. Included among these licensed banks are net providers of foreign currency to the interbank market, on balance reflecting the decisions of the exporters with whom they are associated. The Central Bank of Russia also participates in the MICEX market. Through intervention activities, at times the Central Bank of Russia has pursued target (nominal) exchange rates, as in April through June 1992, or attempted to limit the volatility of exchange rates. ${ }^{20}$ The auction guidelines state that CBR intervention activity should occur

\footnotetext{
${ }^{19}$ Another issue which arose in testing and system specification concerns the choice of data frequency. The frequency of auctions (and of exchange rate and trade volume data) changed during our sample period from weekly, to twice per week, and ultimately to daily sessions. However, the finest frequency in availability of the other variables entering in the regression equations, i.e. the interbank market interest rates and black market premia, is weekly. Two types of regressions were run to deal with this issue. First, we selected a particular day of the week, Tuesdays, and used this date as representative of trading volumes and activities for the week. Second, we constructed weekly weighted sums of order imbalances and weighted averages of initial session exchange rates. Each session within a week is weighted by the ratio of total session volume to the sum of volumes from all sessions during the week. The results are qualitatively similar for all variables except the exchange rate terms. Since the Tuesday data are expected to yield more meaningful results than the weighted variables, we report only those regression sesults.

${ }^{20}$ In the period of our estimation, attempts to manipulate exchenge rates were conducted using foreign exchange sales and less frequently purchases. This contrasts with actions in 1990 and 1991 wherein participants in the auctions sometimes were persuaded by non-price means to limit their activities at particular sessions.
} 
within the trading session, after initial excess demands were observed. Although we cannot verify that these guidelines actually are followed, we also have no immediate means of determining if, when (within a session), and by how much the CBR intervened.

\section{Table 3}

Features of the Data

\begin{tabular}{|c|c|c|c|c|c|c|}
\hline & mean & std.dev. & maximum & minimum & unit root ${ }^{3}$ & trend \\
\hline initial bids ${ }^{1}$ & 46.68 & 28.37 & 146.56 & 2.47 & reject & positive \\
\hline initial offers $^{1}$ & 43.25 & 25.01 & 135.7 & 4.35 & reject & positive \\
\hline real ex.rate & 24.96 & 24.04 & 150.00 & 7.98 & reject & negative \\
\hline REER & 20.66 & 15.23 & 106.00 & 7.98 & reject & negative \\
\hline cash premia ${ }^{2}$ & 9.50 & 10.88 & 31.84 & -21.43 & no reject & none \\
\hline \multicolumn{7}{|c|}{$\begin{array}{l}\text { 1: in millions of US dollars, data from Tuesday auction sessions } \\
\text { 2: cash exchange rate divided by the noncash effective exchange rate } \\
\text { 3: Augmented Dickey-Fuller tests. "Reject" implies rejection of unit root null. }\end{array}$} \\
\hline
\end{tabular}

Periods of exchange rate targeting complicate the interpretation of estimated regression parameters. The main period of targeted exchange rates within our sample, April through June 1992, falls within the interval before our bduml variable is equal to one. At this time, the CBR had effectively announced that a gradual nominal and real appreciation of the ruble would occur. Thus, we would expect that bduml might capture the effects of removing an anticipated appreciation along with the increase in number of auction licenses in Spring 1992. If an ruble appreciation signaled that further appreciations were forthcoming, the sign on the exchange rate term in the supply equation could be the negative rather than positive, as would otherwise be expected.

Two alternative real exchange rate specifications are utilized in our regressions: a real exchange rate (RER) and a real effective exchange rate (REER). "Effective" exchange rates are 
distinguished from observed market exchange rates in that they adjust for foreign exchange surrender (FXS) taxation imposed on exporters. ${ }^{21}$ This adjustment is important mainly for the supply side of the market and is therefore only used in tests of initial offers of foreign exchange. 22

D. Estimation results: Tables 4 and 5 report the results of various specifications of regressions of initial bids and initial offers after elimination of those events-dummy variables that were clearly statistically insignificant. In some regressions, lagged volume data are included as explanatory variables. Their coefficients are interpreted as reflecting dynamic responses to impulses. Some regressions include a trend term, although this term has no true structural interpretation given our description of market fundamentals. ${ }^{23}$

Significance of Fundamental Variables for Foreign Exchange Demand and Supply: On the bid side, reflecting foreign exchange demand, both real interest rates and cash market premia have the expected signs, although the statistical significance of these terms depends on the regression specification. Increasing real interest rates lower the demand for foreign exchange while increasing the cash market premia raise the demand for foreign exchange through legal channels. In periods of price reforms, the RDUM dummy shows that demand for foreign exchange is significantly less than that which the pure interest rate elasticities operating over temporarily high negative annualized real interest rates would predict. The real exchange

\footnotetext{
${ }^{21}$ FXS taxes on exporters selling currency at the auctions have been as large as thirty percent of their earnings. See Goldberg (1993a).

${ }^{22}$ When the relevant exchange rate variable is utilized in equation (1), it is the logarithm of the prior session's $(t-1)$ closing exchange rate since, according to the rules of MICEX, this is the price relevant for initial market bids and offers. Real exchange rates are constructed by deflating the nominal exchange rates from the prior session by the current period's price level. The black market premium is constructed as the ratio of the black market exchange rate to the relevant real exchange rate series.

${ }^{23}$ Some regressions exclude the additive $B d u m 3$ term. The reason for this exclusion is the degree of colinearity between this additive term and the interactive $B d u m 3$ expression. These two series are highly correlated because variability in the real exchange rate is limited during the period in which $B d u m 3$ is defined equal to one.
} 
Table 4 Initial Bids (Demand) for Dollars at MICEX

$$
X_{t}^{\text {initial }}=\alpha_{0}+\alpha_{0, j} B d u m_{t}^{j}+\left(\alpha_{1}+\alpha_{2, j} B d u m_{t}^{j}\right) \cdot R E R_{t-1}+\alpha_{3} \cdot\left(-i_{t-1}+\pi_{t-1}\right)+\alpha_{4} \cdot z_{t}+\alpha_{5} \cdot \delta_{t-1}+\alpha_{6} \cdot X_{t-1}^{\text {initial }}+\mu_{t}
$$

(1)

(2)

(3)

(4)

(5)

\begin{tabular}{|c|c|c|c|c|c|}
\hline lag-1(bid) & & $\begin{array}{l}0.319 * * * \\
(0.095) \\
\end{array}$ & $\begin{array}{l}0.347^{* * *} \\
(0.089) \\
\end{array}$ & & \\
\hline bdum 1 & $\begin{array}{l}-4.328^{*} \\
(2.260)\end{array}$ & $\begin{array}{l}-7.031 * * * \\
(2.080)\end{array}$ & $\begin{array}{l}-7.634 * * * \\
(1.945)\end{array}$ & $\begin{array}{l}-7.344 * * * \\
(2.305) \\
\end{array}$ & $\begin{array}{l}-4.658 * \\
(1.894) \\
\end{array}$ \\
\hline bdum2 & $\begin{array}{l}3.700^{*} \\
(2.078) \\
\end{array}$ & $\begin{array}{l}6.283^{* * *} \\
(2.278) \\
\end{array}$ & $\begin{array}{l}6.439 * * * \\
(2.009) \\
\end{array}$ & $\begin{array}{l}6.909 * * * \\
(2.167) \\
\end{array}$ & $\begin{array}{l}4.872 * \\
(1.926) \\
\end{array}$ \\
\hline bdum 3 & $\begin{array}{l}3.961^{*} \\
(2.395)\end{array}$ & $\begin{array}{l}0.443 \\
(1.531)\end{array}$ & & & \\
\hline Real ER & $\begin{array}{c}-0.817^{*} \\
(0.420)\end{array}$ & $\begin{array}{l}-1.508 * * * \\
(0.533)\end{array}$ & $\begin{array}{l}-1.975^{* * *} \\
(0.411)\end{array}$ & $\begin{array}{l}-1.878 * * * \\
(0.498)\end{array}$ & $\begin{array}{l}-1.167^{* * *} \\
(0.327)\end{array}$ \\
\hline $\begin{array}{l}\text { bdum 1* } \\
\text { Real ER }\end{array}$ & $\begin{array}{l}1.445^{*} \\
(0.758) \\
\end{array}$ & $\begin{array}{l}2.508 * * * \\
(0.734) \\
\end{array}$ & $\begin{array}{l}2.747 * * * \\
(0.685) \\
\end{array}$ & $\begin{array}{l}2.603 * * * \\
(0.812)\end{array}$ & $\begin{array}{l}1.564 * * \\
(0.629)\end{array}$ \\
\hline $\begin{array}{l}\text { bdum2* } \\
\text { Real ER }\end{array}$ & $\begin{array}{l}-1.155^{*} \\
(0.677)\end{array}$ & $\begin{array}{l}-1.937 * * * \\
(0.723) \\
\end{array}$ & $\begin{array}{l}-1.980 * * * \\
(0.640)\end{array}$ & $\begin{array}{l}-2.143 * * * \\
(0.699)\end{array}$ & $\begin{array}{l}-1.521 * * \\
(0.626)\end{array}$ \\
\hline $\begin{array}{l}\text { bdum3* } \\
\text { Real ER }\end{array}$ & $\begin{array}{l}-1.462 \\
(0.910)\end{array}$ & $\begin{array}{l}-0.051 \\
(0.589)\end{array}$ & $\begin{array}{l}0.067 \\
(0.078)\end{array}$ & $\begin{array}{l}0.114 \\
(0.098)\end{array}$ & $\begin{array}{l}0.100 \\
(0.101)\end{array}$ \\
\hline$-\left(i_{t-1}-\pi_{t-1}\right)$ & $\begin{array}{l}0.010 \\
(0.023) \\
\end{array}$ & $\begin{array}{l}0.047 * * \\
(0.047)\end{array}$ & $\begin{array}{l}0.044^{*} \\
(0.025) \\
\end{array}$ & $\begin{array}{l}0.016 \\
(0.025) \\
\end{array}$ & $\begin{array}{l}0.019 \\
(0.025) \\
\end{array}$ \\
\hline $\begin{array}{l}\text { Cash prem- } \\
\text { ium(\#lags) }\end{array}$ & $\begin{array}{l}1.720 * * * \\
(0.629)(\mathrm{t}-1)\end{array}$ & $\begin{array}{l}1.313 * * * \\
(0.490)(\mathrm{t}-1)\end{array}$ & $\begin{array}{l}0.190 \\
(0.526)(\mathrm{t}-2)\end{array}$ & $\begin{array}{l}0.844^{*} \\
(0.522)(t-2)\end{array}$ & $\begin{array}{l}0.740 \\
(0.527)(\mathrm{t}-2)\end{array}$ \\
\hline $\log ($ trend $)$ & & $\begin{array}{l}-0.903^{* *} \\
(0.428)\end{array}$ & $\begin{array}{l}-0.956 * * * \\
(0.346) \\
\end{array}$ & $\begin{array}{l}-0.754^{*} \\
(0.405)\end{array}$ & \\
\hline $\begin{array}{l}\text { constant } \\
\text { tm070392 } \\
\text { tm040193 } \\
\text { ar050692 } \\
\text { ar091592 } \\
\text { Rdum } \\
\text { Parliam } \\
\end{array}$ & $\begin{array}{l}6.058^{* * *} \\
0.533^{*} \\
0.278 \\
-0.863^{* * *} \\
0.455^{*} \\
-0.573^{* *} \\
0.015 \\
\end{array}$ & $\begin{array}{l}9.459 * * * \\
0.427 * * * \\
0.294 * * \\
-0.981 * * * \\
0.500 * * * \\
-0.819 * * * \\
-0.017 \\
\end{array}$ & $\begin{array}{l}10.946 * * * \\
0.400^{*} \\
0.244^{*} \\
-0.953^{* * *} \\
0.555^{* *} \\
-0.629 * * * \\
-0.063\end{array}$ & $\begin{array}{l}11.463^{* * *} \\
0.650^{* *} \\
0.275 \\
-1.075^{* * *} \\
0.464^{*} \\
-0.605^{* *} \\
0.107 \\
\end{array}$ & $\begin{array}{l}7.045^{* * *} \\
0.567^{* *} \\
0.100 \\
-1.109^{* * *} \\
0.462^{*} \\
-0.497^{* *} \\
0.087 \\
\end{array}$ \\
\hline adj. R2 & 0.927 & 0.934 & 0.931 & 0.929 & 0.923 \\
\hline D.W.D.H. & 1.959 & $0.319(\mathrm{DH})$ & $0.567(\mathrm{DH})$ & 1.859 & 1.845 \\
\hline$\rho<1>$ & $0.555^{* * *}$ & & & $0.385^{* * *}$ & $0.411 * * *$ \\
\hline SSR & 7.571 & 6.911 & 7.155 & 7.741 & 8.079 \\
\hline hetero & reject & corrected & reject & reject & reject \\
\hline
\end{tabular}

standard errors in parentheses. $*=10 \%,{ }^{* *}=5 \%, * * *=1 \%$ signficance. $<1>$ Cochrane-Orcutt or Beach-MacKinnon method used. 
Table 5 Initial Offers (Supply) of Dollars at MICEX

$$
X_{t}^{\text {initial }}=\alpha_{0}+\alpha_{0, j} B d u m_{t}^{j}+\left(\alpha_{1}+\alpha_{2, j} B d u m_{t}^{j}\right) \cdot R E R_{t-1}+\alpha_{3} \cdot\left(-i_{t-1}+\pi_{t-1}\right)+\alpha_{4} \cdot Z_{t}+\alpha_{5} \cdot \delta_{t-1}+\alpha_{6} \cdot X_{t-1}^{i n i t i a l}+\mu_{t}
$$

(1)

(2)

(3)

(4)

\begin{tabular}{|c|c|c|c|c|c|}
\hline $\begin{array}{l}\text { lag-1 } \\
\text { (offer) }\end{array}$ & $\begin{array}{l}0.271 * * * \\
(0.092)\end{array}$ & $\begin{array}{l}0.304^{* * *} \\
(0.095)\end{array}$ & $\begin{array}{l}0.314 * * * \\
(0.094)\end{array}$ & & \\
\hline bdum 1 & $\begin{array}{l}-4.159 * * * \\
(1.383)\end{array}$ & $\begin{array}{l}-3.902 * * * \\
(1.420)\end{array}$ & $\begin{array}{l}-3.861 * * * \\
(1.414) \\
\end{array}$ & $\begin{array}{l}-5.218^{* * *} \\
(1.534) \\
\end{array}$ & $\begin{array}{l}-3.750 * * \\
(1.820) \\
\end{array}$ \\
\hline bdum2 & $\begin{array}{l}4.392 * * * \\
(1.480)\end{array}$ & $\begin{array}{l}3.301^{*} \\
(1.713)\end{array}$ & $\begin{array}{l}3.806 * * \\
(1.544)\end{array}$ & $\begin{array}{l}5.608 * * * \\
(1.543)\end{array}$ & $\begin{array}{l}4.384 * * \\
(1.746)\end{array}$ \\
\hline bdum3 & & $\begin{array}{l}0.933 \\
(1.352)\end{array}$ & & & \\
\hline Real EER & $\begin{array}{l}-0.531^{* *} \\
(0.246)\end{array}$ & $\begin{array}{l}-0.498^{*} \\
(0.252)\end{array}$ & $\begin{array}{l}-0.501^{* *} \\
(0.251)\end{array}$ & $\begin{array}{l}-0.779 * * * \\
(0.244)\end{array}$ & $\begin{array}{l}-0.388 \\
(0.358)\end{array}$ \\
\hline $\begin{array}{l}\text { bdum1* } \\
\text { Real EER }\end{array}$ & $\begin{array}{l}1.529 * * * \\
(0.464)\end{array}$ & $\begin{array}{l}1.440^{* * *} \\
(0.476)\end{array}$ & $\begin{array}{l}1.423^{* * *} \\
(0.474)\end{array}$ & $\begin{array}{l}1.925^{* * *} \\
(0.510)\end{array}$ & $\begin{array}{l}1.343^{* *} \\
(0.641)\end{array}$ \\
\hline $\begin{array}{l}\text { bdum2* } \\
\text { Real EER }\end{array}$ & $\begin{array}{l}-1.396 * * * \\
(0.491)\end{array}$ & $\begin{array}{l}-1.022^{*} \\
(0.576)\end{array}$ & $\begin{array}{l}-1.202^{* *} \\
(0.513)\end{array}$ & $\begin{array}{l}-1.776 * * * \\
(0.510)\end{array}$ & $\begin{array}{l}-1.407^{* *} \\
(0.565)\end{array}$ \\
\hline $\begin{array}{l}\text { bdum3* } \\
\text { Real EER }\end{array}$ & $\begin{array}{l}0.293^{* * *} \\
(0.069)\end{array}$ & $\begin{array}{l}-0.057 \\
(0.510) \\
\end{array}$ & $\begin{array}{l}0.291 * * * \\
(0.071)\end{array}$ & $\begin{array}{l}0.361^{* * *} \\
(0.073) \\
\end{array}$ & $\begin{array}{l}0.335^{* * *} \\
(0.076)\end{array}$ \\
\hline$-\left(i_{t-1}-\pi_{t-1}\right)$ & $\begin{array}{l}-0.007 \\
(0.021) \\
\end{array}$ & $\begin{array}{l}0.001 \\
(0.022) \\
\end{array}$ & $\begin{array}{l}0.002 \\
(0.022) \\
\end{array}$ & $\begin{array}{l}-0.021 \\
(0.020) \\
\end{array}$ & $\begin{array}{l}-0.016 \\
(0.020) \\
\end{array}$ \\
\hline $\begin{array}{l}(\mathrm{t}-2) \text { Cash } \\
\text { premium }\end{array}$ & $\begin{array}{l}0.720^{*} \\
(0.370)\end{array}$ & $\begin{array}{l}0.778 * * \\
(0.390)\end{array}$ & $\begin{array}{l}0.720^{*} \\
(0.379)\end{array}$ & $\begin{array}{l}0.792 * * \\
(0.393)\end{array}$ & $\begin{array}{l}0.758 * * \\
(0.392)\end{array}$ \\
\hline $\log ($ trend $)$ & & & & & $\begin{array}{l}0.390 \\
(0.265) \\
\end{array}$ \\
\hline $\begin{array}{l}\text { constant } \\
\text { tx070392 } \\
\text { ar050692 } \\
\text { Rdum } \\
\text { Parliam }\end{array}$ & $\begin{array}{l}3.970^{* * *} \\
0.290^{*} \\
-0.696^{* * *} \\
-0.695^{* * *} \\
0.284\end{array}$ & $\begin{array}{l}3.666^{* * *} \\
0.311^{*} \\
-0.699^{* *} \\
-0.722^{* * *} \\
0.285\end{array}$ & $\begin{array}{l}3.651^{* * *} \\
0.305^{*} \\
-0.693^{* *} \\
-0.720^{* * *} \\
0.290\end{array}$ & $\begin{array}{l}5.652^{* * *} \\
0.447 * * \\
-0.737^{* * *} \\
-0.717^{* * *} \\
0.406^{*}\end{array}$ & $\begin{array}{l}3.409^{* * *} \\
0.329 \\
-0.743^{* * *} \\
-0.663^{* * *} \\
0.397^{*}\end{array}$ \\
\hline adj. R2 & 0.941 & 0.936 & 0.937 & 0.939 & 0.940 \\
\hline $\begin{array}{l}\text { D.W JD.H } \\
\text { (p-value) }\end{array}$ & $\begin{array}{l}0.978 \\
(0.328)\end{array}$ & $\begin{array}{l}0.7291 \\
(0.466)\end{array}$ & $\begin{array}{l}0.5953 \\
(0.552)\end{array}$ & 1.982 & 1.990 \\
\hline SSR & 5.567 & 5.738 & 5.773 & 5.704 & 5.556 \\
\hline hetero & reject & reject & reject & reject & reject \\
\hline$\rho$ & --- & --- & --- & $0.290^{* * *}$ & $0.316^{* * *}$ \\
\hline
\end{tabular}

standard errors in parentheses. $*=10 \%, * *=5 \%, * * *=1 \%$ significance. Cash premium constructed using nominal effective exchange rates. For calculation of autoregressive residual, Beach-MacKinnon methodology is applied. 
rate enters with the expected sign and also is statistically significant: increasing the price of foreign exchange lowers the real demand for foreign exchange.

In Table 5, the offer side, reflecting foreign exchange supply, is insensitive to real interest rates. Nonetheless, the response to exogenous fundamentals does provide evidence that the suppliers of foreign exchange are forward looking: in periods of price reforms there is significantly less supply. Premia of secondary market / cash exchange rates relative to MICEX exchange rates were expected to have a negative effect on supplies to the official auctions, however the effects of this fundamental variable take the wrong sign and are statistically significant. The foreign exchange regime reform of $7 / 3 / 92$ significantly increased currency supply at auction, while the prior announcement (on 5/6/92) of an intention to implement a controlled exchange rate significantly reduced foreign exchange sales.

Import and export policy measures generally did not have statistically significant effects on foreign exchange supply or demand. Among the few import tariff changes with statistically significant effects on foreign exchange demands, the direction of the effect was the opposite of that intended: "stiffer" tariffs were associated with increased rather than reduced foreign exchange demands. As documented by the World Bank (1993), this is most likely due to poor enforcement and increased differentiation. ${ }^{24}$ Laws attempting to increase repatriation of foreign exchange earnings did not lead to significant increases in supply of foreign currency to the auctions. With the exception of the major reform of July 3, 1992, exporters did not modify their use of auctions in response to these laws.

Indication of dynamic micro-market activity: On both sides of the market changes in fundamental variables have persistent effects on market activity. In addition to

\footnotetext{
${ }^{24}$ Another explanation is that the dummies are simply picking up time trends in demand. This explanation is unconvincing since the coefficients on the policy dummies do not uniformly enter with a positive sign.
} 
contemporaneous impacts, the autoregressive term shows an additional thirty percent response in one week, an additional nine percent response in two weeks, and in three weeks the effect is essentially dampened out with an additional three percent response. Overall it takes approximately one month for the effects of a one period policy impulse to be fully realized in the foreign exchange market.

Under-reyelation and Strategic Considerations: We find mixed evidence of strategic under-revelation in Russia's foreign exchange auctions. However, any significant departures from the expected sign patterns on the terms used to test for these effects have clear explanations.

On the demand side the signs and significance patterns on the bduml terms are consistent with reduced transaction volumes and heightened strategic play among market participants. ${ }^{25}$ This result runs counter to our expectations regarding the effects of adding these new players to the market. A plausible explanation is that the dates of the bduml $=1$ closely correspond to the introduction in early September 1992 of a set of restrictive import taxes. It is possible that this sharp increase in taxes reduced the activity of numerous players in the market, while simultaneously strengthening the relative position of a smaller set of dominant players. It was not uncommon for dominant players in the market to negotiate less deleterious import taxes or even exemptions. On the demand side the new entrants indicated by bdum 2 terms lead to market outcomes strongly consistent with reduced strategic play. These additional players both added to total market demands and reduced the monopsony power of existing players. The signs and significance patterns on the bdum3 terms, reflecting the impact on the demand side of the market of tightened bank capitalization requirements, suggest that these measures

\footnotetext{
${ }^{25}$ Recall that bduml and bdum2 represented expanded number of participants in the MICEX market, while bdum 3 reflects a tightening of capitalization requirements for bank activity, a policy initiative aimed at restricting the number of relatively small players in the foreign exchange market.
} 
had little effect on foreign exchange demand.

On the supply side of the market we do not find evidence that new entrants reduced the exercise of market power by existing players. First, as we had anticipated, the basic exchange rate term has a negative sign because during a significant portion of the January to July 1992 interval (when all interactive dummies are zero), real appreciations of the ruble signaled pending further appreciations due to the objectives of the Central Bank of Russia. Sales increased as the ruble appreciated because market participants later bought back their rubles at even lower prices (Goldberg, 1993). This activity ended in May 1992 after a steady loss of foreign exchange reserves resulting in a re-instituted floating exchange rate.

Given the background against which the number of participants in the auction was increased, the interactive bduml term shows that elasticity of supply with respect to exchange rates was of the correct sign and highly significant. When the number of auction participants rose further, corresponding to the $b d u m 2$ terms defined equal to one, the supply curve became flatter and offers of foreign exchange increased. This implies increased volumes but does not suggest a reductions in strategic under-revelation by existing suppliers. The coefficient on the bdum 3 dummy is consistent with reduced under-revelation of demand and does not support the hypothesis that the increased capitalization increased the concentration of market power on the supply side of the auction.

In sum, our empirical analysis supports two main conclusions. First, this foreign exchange market was responsive to macro-economic fundamentals and any related tests of microstructure hypotheses should account for this responsiveness. Moreover, any econometric modeling of exchange rates may be flawed if it neglects the effects of interim variations in market microstructure. Second, most of the observed response to changing the number of market participants appeared on the demand side of the auction, suggesting that among the 
thirty-two banks which initially established MICEX, those acting on the supply side of the market retained power relatively unscathed by new entrants. This is consistent with the perception that the initial supply-side participants were representatives of the major raw materials and related exporting conglomerates in Russia, a dominant source of foreign exchange in Russia.

\section{Relationship to Results in Experimental Economics}

In this section we consider the lessons from experimental economics that may be useful for interpreting our theoretical and empirical results on specific implications of the tâtonnement auction microstructure. The two main themes we address are: (i) is the number of participants in the auction a useful indicator of changes in the competitive structure of the auction? (ii) what is the relationship between the results from the Russian case and the underrevelation patterns observed in experimental tâtonnement auctions? Are there any robust conclusions that we can extract from this relationship?

Although actual studies of auction microstructures are limited by data availability, $a$ priori it is not clear to what extent the number of participants is a good proxy for market concentration. The majority of experimental results on the effects of market concentration come from studies on double auctions, not tâtonnement markets. With very few exceptions, the experiments on double auctions show that convergence to a Walrasian outcome obtains regardless of the number of traders. ${ }^{26}$ Smith and Williams (1989) show that traders do not tend to exert monopoly pricing behavior or to restrict supply in experiments over five monopoly markets and four duopoly markets. However, these results have been attributed to the sequential nature of transactions under a double auction's discriminatory pricing rule. By

\footnotetext{
${ }^{26}$ The original insight is due to Smith (1982). Davis and Holt (1993) provide a summary of related results.
} 
selling units at different prices, the buyers become informed that monopolists are able to make profitable trades at lower prices. In future auctions buyers response by withholding their purchases until prices fall and monopoly rents are dissipated. ${ }^{27}$

For experimental double auctions the only exception to the competitive outcomes result arises with extreme concentrations of market power. Holt et. al. (1986) observe underrevelation when some traders are endowed with a large fraction of the total units supplied to the market. The exercise of monopoly power becomes even more pronounced as traders gain experience. This result also was confirmed in the experiments by Davis and Williams (1991).

The general experimental conclusion that there will be convergence to Walrasian outcomes, regardless of the numbers of players, may not apply to tâtonnement auctions. The competitive or uniform pricing rules of tâtonnement markets do not permit the type of price discrimination observed in the double auctions. Monopolistic actions may remain feasible since withholding (of demand or supply) affects price and surplus for every unit traded. This latter result does not extend to double auctions where withholding only influences the returns on sequential trades and market participants learn more about the bounds of prices acceptable to the monopolist.

Tâtonnement markets have been subjected to relatively few experiments. Evidence of under-revelation behavior has been presented, but this actual practice has been linked to the presence of information asymmetries among experiment participants. A controlled experiment by Joyce (1984) found that (a) both buyers and sellers tend to equally under-reveal when both groups are not segregated, and (b) buyers tend to under-reveal more --and reap larger gains

\footnotetext{
${ }^{27}$ For double auctions, this type of result has led to the conclusion that the institutional features of markets are more important that traditional structural characteristics - like the number of agents -- in determining which market outcomes will correspond to the predictions of the competitive model. Smith (1982) has termed this the "Hayek Hypothesis".
} 
from trade-- than sellers when both groups are segregated. ${ }^{28}$ Bronfman et al. (1994) also ran a set of experiments that allow for multi-unit demand conditions and find that traders underreveal in most cases. Unlike Joyce, these experiments were not characterized by significant differences in under-revelation by net suppliers and net demanders.

In sum, our results together with the experimental evidence at hand suggest that tâtonnement markets with significant market concentration provide incentives for excess demand under-revelation. This under-revelation, which has empirically appeared more strongly on the demand side than on the supply side, leads to relative market thinness.

\section{Concluding Remarks}

The market-determined pricing of foreign exchange is crucial for efficient allocations of productive factors and reduced distortions in trade, especially for developing economies and newly emerging markets. In addition, the real consequences of exchange rates underscore the necessity to understand the implications of the choice of appropriate foreign exchange market microstructures.

In this paper we have studied some of the properties of a particular foreign exchange trading microstructure: the two-sided tâtonnement auction. We have shown that this auction presents participants with a potentially strong motive for excess demand under-revelation. Our results show that strategic play among market participants is likely to lead to lower elasticities of response of excess demand in relation to exchange rate movements and smaller quantities traded in the market. Thus, although the tâtonnement market has the advantage of presenting market participants with a single clear market-determined exchange rate, its disadvantage is the greater potential for agents to manipulate this rate. Because of the potential for strategic under-

\footnotetext{
28 Although this latter result remains an analytical puzzle, Joyce speculated that it could originate in the fact that experimental subjects tend to be more skilled acting as buyers than as sellers.
} 
revelation, the choice of a tâtonnement auction microstructure may result in overall market thinness.

While there have been few empirical analyses of the implications of a particular FOREX auction format, evidence of "strategic quantity reduction" under uniform pricing rules has been confirmed elsewhere. Tenorio (1993a and 1993b) finds evidence in the one-sided foreign exchange auctions implemented in Zambia. Aron and Elbadawi (1993) find support for underrevelation in the Nigerian foreign exchange auctions: banks generally did not bid for their full allowed quotas of foreign exchange in competitive auctions, while they did bid their full quotas in discriminatory auctions.

Policy-makers considering alternative auction structures have recognized the importance of increasing competition and expanding access to thin markets (Quirk et al., 1987). These insights are born out by the theoretical and empirical results that we have provided in this paper. New entrants can reduce the concentration of market power and the ability of existing agents to manipulate prices. In Russian markets the new entrants appeared to reduce strategic under-revelation mainly on the demand side of the market, while the supply side competitive structure remained mostly unaffected.

Finally, the choice of foreign exchange market microstructure also may have important implications for market efficiency and volatility. The studies by Bulow and Klemperer (1994) and Madhavan (1992) show that markets that clear through a sequence of trades, as does the double auction, are more likely to result in higher price volatility than markets with batch trading, like tâtonnement. Both of these papers emphasize that suboptimal diffusion of information takes place in a sequential trade market. Indeed, Madhavan also shows that, in a batch auction, informational asymmetries among players can present conditions for greater market efficiency at information aggregation than observed in the continuous double auction. 
In closing, our view is that the study of foreign exchange markets can draw and build upon important lessons from market microstructure theory, experimental work, and related empirical analyses. This merging of lessons is an open area for research. Although a host of literature exists on tradeoffs related to the choice of exchange rate regimes, i.e. fixed versus flexible, and on the statistical properties of exchange rates, a comparable body of work is lacking on the interaction between exchange rate determination and the market microstructure used to implement foreign exchange trade.

\section{References}

Agénor, Pierre Richard and Peter Monteil (1995), Development Macroeconomics (Princeton University Press).

Aron, Janine and Ibrahim Elbadawi (1993), "A Typology of Foreign Exchange Auction Markets in Sub-Saharan Africa," mimeo, The World Bank.

Bronfman, Corine, Kevin McCabe, David Porter, Stephen Rassenti, and Vernon Smith (1994), "An Experimental Examination of the Walrasian Tatonnement Mechanism," mimeo.

Bulow, Jeremy and Paul Klemperer (1994), "Rational Frenzies and Crashes," Journal of Political Economy, vol. 102 pp.1-23.

Davis, Douglas and Charles Holt (1993), Experimental Economics, (Princeton University Press, Princeton N.J.)

Davis, Douglas and Arlington Williams (1991), "The Hayek Hypothesis in Experimental Auctions: Institutional Effects and Market Power," Economic Inquiry, vol.29 pp.261-274.

Feldman, Robert and Rajnish Mehra (1993), "Auctions: Theory and Possible Applications to Economies in Transition," International Monetary Fund Staff Papers (December).

Friedman, Daniel (1993), "The Double Auction Market Institution: A Survey," in eds. Daniel Friedman and John Rust, The Double Auction Market: Institutions, Theories, and Evidence (Addison-Wesley).

Goldberg, Linda (1993), "Foreign Exchange Markets in Russia: Understanding the Reforms," Staff Papers International Monetary Fund vol. 40 no.4 (December) pp.852-864.

Goldberg, Linda, (1995) "Exchange Rate Unification with Black Market Leakages," Journal of Development Economics (forthcoming). 
Goldberg, Linda and Il'dar Karimov (1995a),"Policy Initiatives, Currency Markets and Production Choices in Emerging Market Economies," Journal of Comparative Economics (forthcoming).

Goldberg, Linda and I'dar Karimov (1995b), "Black Markets for Currency, Hoarding Activity and Policy Reform," revised manuscript, New York University.

Goldberg, Linda and Rafael Tenorio, "Explaining Order Imbalances in Russia's Tâtonnement Foreign Exchange Auction," in eds. János Gács and Merton J. Peck, International Trade Issues of the Russian Federation (IIASA, Austria, 1995).

Holt, Charles, Loren Langan, and Anne Villamil (1986), "Market Power in Oral Double Auctions," Economic Inquiry, vol.24, pp.107-123.

Hurwicz, Leonid (1972), "On Informationally Decentralized Systems," in Decision and Organization, edited by C.B. McGuire and Roy Radner (Univerisity of Minnesota Press, Minneapolis).

Jarecki, Henry G. (1976), "Bullion Dealing, Commodity Exchange Trading and the London Gold Fixing: Three Forms of Commodity Auctions," in Bidding and Auctioning for Procurement and Allocation, edited by Yakov Amihud (New York University Press, New York).

Joyce, Patrick (1984), "The Walrasian Tâtonnement Mechanism and Information," Rand Journal of Economics, vol. 15, pp.416-425.

Kovanen, Arto (1994), "Foreign Exchange Auctions and Fixing: A Review of Performance," International Monetary Fund, working paper (September).

Lyons, Richard (1993), "Tests of Microstructure Hypotheses in the Foreign Exchange Market," NBER working paper \#4471, Journal of Financial Economics (forthcoming)

Madhavan, Ananth (1992), "Trading Mechanisms in Securities Markets," Journal of Finance vol. 47 no. 2 pp.607-642.

MICEX (1992), Moscow Interbank Currency Exchange (MICEX), (Image: Moscow, Russia) Morishima, Michio (1977), Walras' Economics (Cambridge University Press: Cambridge).

Quirk, Peter, B.V. Christensen, K. Huh, and T. Sasaki (1987), "Floating Exchange Rates in Developing Countries: Experience with Auction and Interbank Markets," International Monetary Fund Occasional Paper \#53.

Samuelson, Paul (1954), "The Pure Theory of Public Expenditure," Review of Economics and Statistics, vol. 36 pp.387-389. 
Schmeidler, David (1980), "Walrasian Analysis via Strategic Outcome Functions," Econometrica vol.48 pp.1585-1593.

Smith, Vernon (1982), "Markets as Economizers of Information: Experimental Examination of the 'Hayek Hypothesis'," Economic Inquiry, vol.20, pp.165-179.

Smith, Vernon and Arlington Williams (1989), "The Boundaries of Competitive Price Theory: Convergence, Expectations, and Transactions Costs." In Advances in Behavioral Economics, ed. L. Green and J. Kagel, vol. 2 (Norwood, NJ: Ablex).

Tenorio, Rafael (1993a), "Revenue-Equivalence and Bidding Behavior in a Multi-Unit Auction Market: An Empirical Analysis" Review of Economics and Statistics vol.75 pp.302-314. (1993b), "On Strategic Quantity Bidding in Multiple Unit Auctions," mimeo, Notre Dame (March).

Vickrey, William (1961), "Counterspeculation, Auctions, and Competitive Sealed Tenders," Journal of Finance vol.16 pp.8-37.

Walker, Donald A. (1972), "Competitive Tâtonnement Exchange Markets," Kyklos vol. 25 pp.345-363.

World Bank (1993), Russia: Joining the World Economy (Washington, D.C.) 


\section{Appendix A: A Typical Trader's Problem Allowing for Intertemporal Decisions}

In Section IIA we showed that strategic under-revelation occurs in a tâtonnement foreign exchange market where agents trade for financing import purchases or selling proceeds from contemporaneous export transactions. In countries where market participation is limited to current-account related transactions, the model we presented appropriately portrays the spirit of market formation. However, in practice, even a market established for clearing current account transactions may be subject to foreign exchange speculation by under- or overinvoicing transactions. ${ }^{29}$ In this appendix we show that under-revelation remains important if both real trade in goods and pure speculative motives are introduced. Indeed, the existence of pricing power in foreign exchange auctions can actually limit the amount of speculation that occurs in response to anticipated real exchange rate movements.

As in Section IIA, the trader $i$ 's objective is:

$\operatorname{Max}_{x_{i}} V_{i}\left(x_{i}\right)-e\left(x_{i}+\sum_{j=1, x i}^{n} x_{j}\right) x_{i}$

We now redefine trader $i$ 's value function as:

$V_{i}\left(x_{i}\right)=\lambda \cdot T_{i}\left(x_{i}\right)+(1-\lambda) \cdot f\left(E_{t} e_{t+1}\right) x_{i}$

This function has two components. $T_{i}\left(x_{i}\right)$ is the value of buying foreign exchange for import purposes $\left(x_{i}>0\right)$ or of selling foreign exchange from export proceeds $\left(x_{i}<0\right) . f\left(E_{t} e_{t+1}\right) x_{i}$ reflects the value of intertemporal speculation: agents expecting a currency depreciation place a higher value on current foreign exchange holdings. $f\left(E_{t} e_{t+1}\right)>0$ and $f^{\prime}\left(E_{t} e_{t+1}\right)>0$. The parameter $\lambda>0$ reflects the relative importance of the two motives. The model in IIA is generated as a special case where $\lambda=1$.

The necessary and sufficient optimality condition for (a1)-(a2) is:

$\lambda T_{i}^{\prime}\left(x_{i}^{*}\right)+(1-\lambda) f\left(E_{t} e_{t+1}\right)=e(\cdot)\left[1+\frac{s_{i}}{\varepsilon}-(1-\lambda) f^{\prime}\left(E_{t} e_{t+1}\right) \frac{\partial E_{t} e_{t+1}}{\partial x_{i}} \cdot \frac{x_{i}}{e_{t}}\right]$

\footnotetext{
${ }^{29}$ Agenor and Monteil (1995) provide a comprehensive discussion of forms of speculation when there are current or capital account controls in developing countries. Goldberg and Karimov (1995a, 1995b) consider the linkages between foreign exchange auction markets and black markets in the context of emerging market economies.
} 
Notice that the static strategic under-revelation term of Section IIA, $s_{i} / \varepsilon$, remains in this dynamic framework. However, an additional term appears on the right hand side of the first order condition. We gain insight into the size and sign of this term by deriving an expanded form for the expression $\partial E_{t} e_{t+1} / \partial x_{i}$ :

$$
\frac{\partial E_{t} e_{t+1}\left(x_{i, t+1}+\sum_{j=1, \neq i}^{n} x_{j, t+1}\right)}{\partial x_{i}} \cdot \frac{x_{i}}{e_{t}}=\left(\frac{\partial E_{t} e_{t+1}}{\partial x_{i, t+1}} \cdot \frac{\partial x_{i, t+1}}{\partial x_{i, t}}+\sum_{j=1, \neq i}^{n} \frac{\partial E_{t} e_{t+1}}{\partial x_{j, t+1}} \cdot \frac{\partial x_{j, t+1}}{\partial x_{i, t}}\right) \cdot \frac{x_{i}}{e_{t}}
$$

which can be expressed in terms of elasticities as follows:

$$
\frac{\partial E_{t} e_{t+1}\left(x_{i, t+1}+\sum_{j=1, \neq i}^{n} x_{j, t+1}\right)}{\partial x_{i}} \cdot \frac{x_{i}}{e_{t}}=E_{t}\left(\frac{e_{t+1}}{e_{t}}\right) \cdot\left(\frac{s_{i}}{\varepsilon_{i}} \cdot \eta_{x i, t+1}+\sum_{j=1, \neq i}^{n} \frac{s_{j}}{\varepsilon_{j}} \cdot \eta_{x j, t+1}\right)
$$

where $\eta_{x, t+1}$ and $\eta_{x, t+1}$ are elasticities of $x_{i, t+1}$ and $x_{j, t+1}$, respectively, with respect to $x_{i, t}$.

The right hand side of equation (a5) shows that intertemporal speculation changes present demands for foreign exchange through two factors. The first depends $i$ 's market share, the elasticity of $e_{\mathfrak{t}+1}$ with respect to $x_{i, t+1}$, and the degree to which the change in current demand displaces future demands, i.e. on the size and sign of $\eta_{x i, t+1}$. The second factor depends on the market share of agents $j$ and how $i$ perceives that these agents will adjust their period $t+l$ positions upon observing $i$ 's actions at $t$, i.e. on the size and sign of $\eta_{x, i+1}$. Assuming that i's and j's quantities are intertemporal strategic substitutes, $\eta_{x, t+1}<0$.

Substituting (a5) back into (a3) provides the full exposition of the different factors affecting underrevelation:

$\lambda T_{i}^{\prime}\left(x_{i}^{*}\right)+(1-\lambda) f\left(E_{t} e_{t+1}\right)=e(\cdot)\left[1+\frac{s_{i}}{\varepsilon_{i}}-(1-\lambda) f^{\prime}\left(E_{t} e_{t+1}\right) \cdot E_{t}\left(\frac{e_{t+1}}{e_{t}}\right) \cdot\left(\frac{s_{i}}{\varepsilon_{i}} \cdot \eta_{x, s+1}+\sum_{j=1, t i}^{n} \frac{s_{j}}{\varepsilon_{j}} \cdot \eta_{x, s+1}\right)\right]($

where the entire bracketed expression on the right-hand side is negative, i.e. agent $i$ under- 
reveals his true marginal valuation of foreign exchange. ${ }^{30}$

The overall importance of the two speculation-related forces depend on the size of the initial expected devaluation and on the slope of the speculation function, $f(\cdot)$. Observe that under-revelation also is important for speculative activity. If a depreciation is anticipated, agents reduce their current speculative demands if they recognize that their actions influence the price they pay for all foreign exchange purchases undertaken today and in the future. Agent $i$ understands that his increased demand today raises the immediate purchase price on all units, and reduces the expected return when and if these units are resold in the future. Market power in the auctions reduces the intertemporal speculation by agent $i$ and reinforces the strategic under-revelation behavior that is observed in the purely static problem.

Appendix B: Data, Sources and Definitions. The auction/ interbank market sessions were weekly from April 1991 through March 24, 1992, and then were held biweekly until June 9, 1993 when trading expanded to 4 sessions per week. As of June 21, 1993 trading sessions were held daily. For each auction date we have data for market-clearing exchange rates and transaction volumes. We also have information on initial bids and initial offers at the trading sessions, encompassing the last three quarters of 1991 (quarterly data) and at each auction session between January 1992 and the end of sample. Other data used in estimation include:

- Black market exchange rates, generally reported weekly. Source: Commersant.

- CPI, available monthly for periods preceding October 1992 and also available weekly for periods after October 1992. Source: Russian Economic Trends.

- Interbank interest rate series. Source: Commersant.

- The "effective" MICEX rate adjusts for taxes that accrue simply for accessing the official market. Following Goldberg (1993a) and The World Bank (1993), the effective exchange rate $(E E R)$ is defined as follows: Prior to $7 / 3 / 1992: E E R_{1}=0.4 *(55)+0.1^{*}(90)+$ $0.5^{*}$ (MICEX exchange rate); $3 / 1 / 1993$ to end of sample: $E E R_{t}=$ MICEX exchange rate; 11/1/1993-3/1/1993: $E E R_{t}=($ Micex rate $) *\left(.7+.3\left(1-\pi_{t}^{w}\right)^{8}\right)$ using weekly inflation rate; 3/1/1993 to end of sample: $E E R_{t}=$ MICEX exchange rate.

\footnotetext{
${ }^{30}$ Observe that, given $\lambda<1$ and $s_{j}<1$, underrevelation would hold even if there was some intertemporal complementarity between i's and j's quantities, i.e. if $\eta_{x j, t+1}<0$.
} 


\begin{tabular}{|c|c|}
\hline $\begin{array}{l}\text { Appendix } \\
\text { Table } 1\end{array}$ & $\begin{array}{l}\text { Discrete Events Influencing Supply and Demand for Currency at } \\
\text { MICEX }\end{array}$ \\
\hline \multirow[t]{3}{*}{$7 / 3 / 92$} & $\begin{array}{l}\text { Increased taxation of exports (although exemptions are granted over time } \\
\text { and presumably dampened the effectiveness of this initiative). Reduced } \\
\text { effective taxation of exporters through foreign exchange surrender regime. }\end{array}$ \\
\hline & Increased tariffs on imports. \\
\hline & $\begin{array}{l}\text { CBR gets reduced FXS revenues from exporters (although the CBR } \\
\text { gradually regains these revenues in the last quarter of } 1992 \text { and first quarter } \\
\text { of } 1993 \text { by delaying crediting accounts of exporters with rubles for } \\
\text { surrendered foreign exchange.) }\end{array}$ \\
\hline 9/1/92 & Increase in import tariffs \\
\hline $2 / 1 / 93$ & Increase in import tariffs \\
\hline $\begin{array}{l}3 / 9 / 93 \& \\
3 / 23 / 93\end{array}$ & $\begin{array}{l}\text { Laws tightening regulation of foreign exchange earnings from exporting and } \\
\text { attempting to improve repatriation. Nonresidents admitted to currency } \\
\text { exchange as seller; increased restrictions on who can purchase foreign } \\
\text { exchange. }\end{array}$ \\
\hline $4 / 1 / 93$ & Increase in import tariffs \\
\hline $7 / 1 / 93$ & $\begin{array}{l}\text { Foreign exchange surrender system altered: exporters to sell portion of } \\
\text { foreign exchange earnings directly on MICEX instead of turning this over to } \\
\text { the CBR. This could imply improved compensation terms for exporters } \\
\text { (since CBR can't delay ruble account crediting). This also would imply } \\
\text { reduced FOREX revenues of CBR (and reduced CBR ability to intervene in } \\
\text { the FOREX market.) }\end{array}$ \\
\hline
\end{tabular}




\begin{tabular}{|l|l|}
\hline $\begin{array}{l}\text { Appendix } \\
\text { Table 2 }\end{array}$ & Announcements and Rumors \\
\hline $5 / 6 / 92$ & $\begin{array}{l}\text { Government announces that ruble will be appreciated to 80R/\$ on 7/1/92. } \\
\text { Rumors also begin about CBR running out of reserves for defense of target } \\
\text { exchange rates. This set of expectations triggers round-tripping foreign } \\
\text { exchange activities by banks. }\end{array}$ \\
\hline $6 / 23 / 92$ & Rumors circulate about a pending monetary reform in Russia. \\
\hline $9 / 15 / 92$ & Government announces that energy price hikes will occur on 11/1/92. \\
\hline $1 / 19 / 93$ & $\begin{array}{l}\text { Seventh Congress of People's Deputies adopts resolution which essentially } \\
\text { calls for increased deficit spending. This resolution is not yet approved by the } \\
\text { government. }\end{array}$ \\
\hline $2 / 5 / 93$ & $\begin{array}{l}\text { CBR announcement that it may soon fix the ruble/dollar rate. Retraction few } \\
\text { days later. }\end{array}$ \\
\hline $3 / 31 / 93$ & $\begin{array}{l}\text { Rumors on CBR plans to restrict the import of foreign cash by banks from } \\
\text { their correspondent accounts abroad. }\end{array}$ \\
\hline $7 / 12-19 / 93$ & $\begin{array}{l}\text { Rumors circulate about government plan to swap money. Monetary reform } \\
\text { occurs week of } 7 / 24 / 93, \text { whereby pre-1993 ruble notes are invalidated. }\end{array}$ \\
\hline
\end{tabular}

